\title{
Carbon stock and humification index of organic matter affected by sugarcane straw
}

\section{and soil management}

Aline Segnini ${ }^{1}$, João Luís Nunes Carvalho², Denizart Bolonhezi ${ }^{3}$, Débora Marcondes Bastos Pereira Milori ${ }^{*}$, Wilson Tadeu Lopes

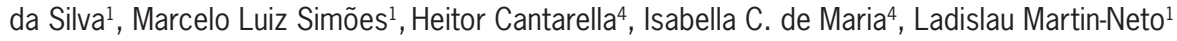

'Embrapa Instrumentação, R. XV de Novembro, 1452 13560-970 - São Carlos, SP - Brasil. ${ }^{2}$ CNPEM/CTBE - Laboratório Nacional de Ciência e Tecnologia do Bioetanol, Polo II de Alta Tecnologia, R. Giuseppe Máximo Scolfaro, 10.000 - 13083-970 -

Campinas, SP - Brasil.

${ }^{3}$ APTA, Centro Leste, Av. Bandeirantes, 2419 - 14030-670 Ribeirão Preto, SP - Brasil.

${ }^{4} \mathrm{AC}$, Av. Barão de Itapura, 1481 - 13012-970 - Campinas, SP - Brasil.

*Corresponding author <debora.milori@embrapa.br>

Edited by: Carlos Eduardo Pellegrino Cerri

Received September 17, 2012

Accepted March 04, 2013

\begin{abstract}
The maintenance of sugarcane (Saccharum spp.) straw on a soil surface increases the soil carbon (C) stocks, but at lower rates than expected. This fact is probably associated with the soil management adopted during sugarcane replanting. This study aimed to assess the impact on soil $\mathrm{C}$ stocks and the humification index of soil organic matter (SOM) of adopting notillage (NT) and conventional tillage (CT) for sugarcane replanting. A greater $\mathrm{C}$ content and stock was observed in the NT area, but only in the $0-5 \mathrm{~cm}$ soil layer $(p<0.05)$. Greater soil $C$ stock $(0-60 \mathrm{~cm}$ ) was found in soil under NT, when compared to CT and the baseline. While $C$ stock of $116 \mathrm{Mg} \mathrm{ha}^{-1}$ was found in the baseline area, in areas under CT and NT systems the values

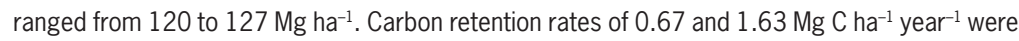
obtained in areas under CT and NT, respectively. Laser-Induced Fluorescence Spectroscopy showed that CT makes the soil surface $(0-20 \mathrm{~cm})$ more homogeneous than the NT system due to the effect of soil disturbance, and that the SOM humification index $\left(\mathrm{H}_{\mathrm{LF}}\right)$ is larger in CT compared to NT conditions. In contrast, NT had a gradient of increasing $\mathrm{H}_{\mathrm{LF}}$, showing that the entry of labile organic material such as straw is also responsible for the accumulation of $\mathrm{C}$ in this system. The maintenance of straw on the soil surface and the adoption of NT during sugarcane planting are strategies that can increase soil $\mathrm{C}$ sequestration in the Brazilian sugarcane sector. Keywords: Laser-Induced Fluorescence Spectroscopy, sugarcane replanting, crop residues, notillage, soil organic matter
\end{abstract}

\section{Introduction}

Brazil is the largest producer of sugarcane (Saccharum spp.), producing 571 million tons from an area of 8.34 million hectares in the 2011/2012 harvest. The south-central region and the state of Sao Paulo accounted for 88 and $54 \%$ of the national production of sugarcane, respectively $(\mathrm{CONAB}, 2011)$.

In the 2000s, the production system relating to sugarcane fields has undergone profound changes. Among the main changes, the gradual elimination of sugarcane burning and an increase in the area of mechanical harvesting can be highlighted. Mechanical harvesting without burning results in the maintenance of 7-30 Mg ha ${ }^{-1}$ year $^{-1}$ of straw (in dry mass), which in most areas is left on the soil surface (Trivelin et al., 1995; Oliveira et al., 1999; Robertson and Thorburn, 2007). Due to the energy potential of sugarcane straw, the industry has shown interest in its use both for electricity generation and for cellulosic ethanol production. Despite this growing interest in the industrial sector, the maintenance of the straw on the soil surface increases soil carbon (C) stocks (Galdos et al., 2009), promotes nutrient cycling (Oliveira et al., 1999), increases soil biological activity (Souza et al., 2012a), reduces weed infestation (Monquero et al., 2008), reduces soil erosion (Sparovek and Schnug, 2001) and increases sugarcane yield (Trivelin et al., 2002). On the other hand, the maintenance of large amounts of straw on the soil surface can result in some negative impacts (Magalhães et al., 2012).
Cerri et al. (2011) compiled the main studies for south-central Brazil and concluded that the maintenance of straw on the soil surface accumulates an average of $1.5 \mathrm{Mg} \mathrm{C} \mathrm{ha}{ }^{-1}$ year $^{-1}$. However, according to these authors, the lowest accumulation rates are observed in areas where soil disturbance and sugarcane replanting is recent $(<2$ years), indicating that much of the $\mathrm{C}$ accumulated during the sugarcane cycle (plant cane and ratoons) is lost during this process. There is currently a gradual reduction in the use of tillage operations and increase of no-tillage (NT) management in Brazil, especially in areas under soybean and maize production (FEBRAPDP, 2012). However, in most areas of sugarcane cultivation, tillage operations, such as plowing, disking and subsoiling, are still widely used in sugarcane replanting. It is therefore critical that long-term studies are conducted, assessing $\mathrm{C}$ accumulation rates and the further stability of this $\mathrm{C}$ in the soil due to the adoption of NT in sugarcane fields. This study aimed to assess the impact on soil $\mathrm{C}$ stock and the humification index of soil organic matter (SOM) of the adoption of NT and conventional tillage (CT) for sugarcane replanting.

\section{Materials and Methods}

Field experiment and management systems

The field experiment was carried out with samples from a Rhodic Hapludox located in Ribeirão Preto $\left(21^{\circ} 12^{\prime} \mathrm{S}\right.$ and $\left.47^{\circ} 52^{\prime} \mathrm{W}\right)$, São Paulo State, Brazil. The 
mean particle size distribution for the surface layer (0-20 $\mathrm{cm}$ ) from this Oxisol comprised $57 \%$ clay, $32 \%$ silt and $11 \%$ sand. Mean annual temperature is $21.6{ }^{\circ} \mathrm{C}$ with a mean annual precipitation of approximately 1,454 $\mathrm{mm}$.

The trial started in 1998 in a commercially harvested green sugarcane field at its $5^{\text {th }}$ ratoon, which had been planted in 1993 (Table 1). An experimental randomized block design with three replications was used with two management systems: CT (moldboard plowing, $30 \mathrm{~cm}$ depth followed by two applications of offset disk harrow) and NT (crop residues left on its surface after spraying the area with $3.6 \mathrm{~kg} \mathrm{ha}^{-1}$ a.i. of glyphosate $-\mathrm{C}_{3} \mathrm{H}_{8} \mathrm{NO}_{5} \mathrm{P}$ ). The amount of straw added annually in the two systems was approximately the same (12-15 Mg ha-1); however, the incorporation of straw (in CT) or not (in NT) in the soil was the difference between these two systems. In NT, the straw was only left on the soil surface. The first and second soil disturbances in the CT area were performed in 1998 and 2003, respectively. Crop rotation with soybean (Glycine max) was carried out in both periods of sugarcane replanting. The first and second soybean crops were planted in Dec. 1998 and Nov. 2003, respectively. Sugarcane crops were planted in Apr. 1999 and in Mar. 2004. In 1998, at the beginning of the experimental period, soil chemical characteristics were determined (at $20 \mathrm{~cm}$-depth) according to methods described in van Raij et al. (2001), and the results were as follows: $\mathrm{pH}$ $\left(0.01 \mathrm{M} \mathrm{CaCl}_{2}\right)=4.8 ; \mathrm{SOM}=31 \mathrm{~g} \mathrm{dm}^{-3} ; \mathrm{P}($ resin $)=23$ $\mathrm{mg} \mathrm{dm}{ }^{-3} ; \mathrm{K}=0.8 \mathrm{mmol}_{\mathrm{c}} \mathrm{dm}^{-3} ; \mathrm{Ca}=24 \mathrm{mmol}_{\mathrm{c}} \mathrm{dm}^{-3} ; \mathrm{Mg}$ $=7.2 \mathrm{mmol}_{\mathrm{c}} \mathrm{m}^{-3} ; \mathrm{H}+\mathrm{Al}=43.9 \mathrm{mmol}_{\mathrm{c}} \mathrm{dm}^{-3}$; cation exchange capacity pH 7 (CEC) $=75.8 \mathrm{mmol}_{\mathrm{c}} \mathrm{dm}^{-3}$; and base saturation $(\mathrm{V})=41 \%$.

\section{Soil sampling and $\mathrm{C}$ stock calculation}

The first soil sampling was conducted in 1998 (baseline, sampled before the soil tillage and sugarcane replanting) and in 2005 (end of the experimental period). Soil samples were collected from different depths: $0-5,5-10,10-20$ and $20-60 \mathrm{~cm}$, in three field replicates.
Samples were collected for the quantification of total C, soil bulk density and index of soil $\mathrm{C}$ humification. Undisturbed samples were collected using a steel cylinder $(5 \times 5 \mathrm{~cm})$ to determine soil bulk density, and pooled for the subsequent evaluation of dry soil weight $\left(105^{\circ} \mathrm{C}\right)$. Soil samples were dried, sieved at $2 \mathrm{~mm}$ and $10 \mathrm{~g}$ of sample were ground and sieved at $0.25 \mathrm{~mm}$ in order to determine $\mathrm{C}$ content. The total $\mathrm{C}$ content was determined by dry combustion, according to Nelson and Sommers (1982), using a C Analyzer-LECO model CR 412.

The $\mathrm{C}$ stock $\left(\mathrm{Mg} \mathrm{ha}^{-1}\right)$ of each soil layer was calculated according to Equation 1:

$\mathrm{C}$ stock $=\mathrm{C} \times \mathrm{BD} \times$ layer depth

where $\mathrm{C}$ is the $\mathrm{C}$ content (\%), BD is the soil bulk density in $\mathrm{Mg} \mathrm{m}^{-3}$ and layer depth is the layer thickness $(\mathrm{cm})$.

Because samples were collected from fixed layers, the $\mathrm{C}$ stocks were adjusted for changes in bulk density that occurred as a result of changes in management. Therefore, the methodology described by Ellert and Bettany (1995) and Sisti et al. (2004) was used to correct soil $\mathrm{C}$ stocks to an equivalent soil mass, using the baseline area as reference.

\section{Estimate of annual $\mathrm{C}$ retention rates}

Carbon retention rates $\left(\mathrm{Mg} \mathrm{C}\right.$ ha $^{-1}$ year $\left.^{-1}\right)$ in the 0-60 cm soil layer of CT and NT areas were calculated according to Equation 2, using the baseline and the period of the two soil samplings (1998 and 2005):

$\mathrm{C}$ retention rate $=\left[\mathrm{C}\right.$ stock ${ }_{(\mathrm{NT} \text { or } \mathrm{CT})}-\mathrm{C}$ stock $\left.{ }_{(\text {baseline) }}\right]$ / 7 (years)

Soil $\mathrm{C}$ humification index determination by LaserInduced Fluorescence Spectroscopy

Laser-Induced Fluorescence Spectroscopy (LIFS) of the soil samples was used to assess the SOM humification (Milori et al., 2006; González-Pérez et al., 2007; Segnini et al., 2010, 2011; Milori et al., 2011). Homogenized

Table 1 - Historical information and descriptions of the management practices in the evaluated areas under conventional tillage (CT) and no-tillage (NT) systems.

\begin{tabular}{|c|c|c|}
\hline \multirow[t]{2}{*}{ Period } & \multicolumn{2}{|c|}{ Historical information and descriptions of the management practices } \\
\hline & CT & NT \\
\hline 1993 & \multicolumn{2}{|c|}{ CT with moldboard plowing followed by two applications of offset disk harrow, furrowing planting } \\
\hline 1994-1998 & \multicolumn{2}{|c|}{ Sugarcane planting and cultivation (variety IAC86-2211) } \\
\hline 1998 & \multicolumn{2}{|c|}{ First soil sampling (baseline) } \\
\hline 1998 & $\begin{array}{c}\text { CT with moldboard plowing followed by two applications of } \\
\text { offset disk harrow }\end{array}$ & NT adoption only with desiccation of the sugarcane ratoon \\
\hline 1998 & Soybean planting & Soybean planting \\
\hline 1999-2003 & Sugarcane planting and cultivation (variety IAC86-2211) & Sugarcane planting and cultivation (variety IAC86-2211) \\
\hline 2003 & $\begin{array}{c}\text { CT with moldboard plowing followed by two applications of } \\
\text { offset disk harrow }\end{array}$ & NT adoption only with desiccation of the sugarcane ratoon \\
\hline 2003 & Soybean planting & Soybean planting \\
\hline $2004-2005$ & Sugarcane planting and cultivation (variety IAC91-2218) & Sugarcane planting and cultivation (variety IAC91-2218) \\
\hline 2005 & Second soil sampling & Second soil sampling \\
\hline
\end{tabular}


soil samples were used to produce pellets. Pellets were prepared with a hydraulic press using approximately 0.5 $\mathrm{g}$ of soil and applying 1,300 $\mathrm{MPa}$ for $5 \mathrm{~min}$. The pellets were approximately $2 \mathrm{~mm}$ thick and $10 \mathrm{~mm}$ in diameter. Two pellets for each soil sample were made. These soil pellets were inserted into a bench custom-made apparatus in order to acquire the LIFS data. The two faces of the pellet were measured, in four replicates. Samples were excited with $458 \mathrm{~nm}$ blue radiation, emitted by argon laser equipment (Coherent Innova 90-6, Coherent Inc., Santa Clara, CA) with power of around $300 \mathrm{~mW}$ (Milori et al., 2006). The system apparatus was assembled and data was acquired according to Milori et al. (2006). The ratio of the area under this fluorescence emission per total $\mathrm{C}$ content (in $\mathrm{g} \mathrm{kg}^{-1}$ ) was defined as the SOM humification index $\left(\mathrm{H}_{\mathrm{LIF}}\right)$ and is expressed as arbitrary units (a.u.) (Milori et al., 2006). The humification of organic matter present in the soil samples was associated with complex SOM structures, such as condensed groups of aromatic rings and quinone-type structures.

\section{Statistical analysis}

A comparison was made of soil $\mathrm{C}$ content, $\mathrm{C}$ stock and $\mathrm{H}_{\mathrm{LIF}}$ from the baseline and areas under different soil management systems, using analysis of variance (ANOVA). A Tukey test was used to compare the means $(p<$ 0.05).

\section{Results and Discussion}

\section{Soil $\mathrm{C}$ content and stock}

Table 2 presents the results for soil $\mathrm{C}$ content and stock from two sugarcane management systems /CT and $\mathrm{NT}$ ) compared to the baseline area. A greater C content was observed in NT soil, but only in the $0-5 \mathrm{~cm}$ soil layer $(p<0.05)$. At layers 5-10, 10-20 and 20-60 cm, it was not possible to differentiate the $\mathrm{C}$ content of the two management systems and the baseline. In the $1^{\text {st }}$ layer of the soil $(0-5 \mathrm{~cm})$, the soil $\mathrm{C}$ content in the NT area was $23 \%$ and $21 \%$ higher than CT and baseline, respectively.
Soil C stocks had a similar behavior in relation to $\mathrm{C}$ content (Table 2$)$. Differences $(p<0.05)$ were only observed in the superficial layer $(0-5 \mathrm{~cm})$ and consequently in the $0-60 \mathrm{~cm}$ equivalent soil layer. These results are consistent with those obtained from areas under NT with other crops, where the largest variations in C stocks occur in the topsoil (Sá et al., 2001; Bayer et al., 2006). Longer periods of maintaining straw on the soil increase the concentration of $\mathrm{C}$ on the soil surface (Blair et al., 1998; Galdos et al., 2009; Thorburn et al., 2012). Higher total C stock $(0-60 \mathrm{~cm})$ was found in soil under NT in comparison with the baseline (Table 2). While a $\mathrm{C}$ stock of $116 \mathrm{Mg} \mathrm{ha}^{-1}$ was found in the baseline area, the values ranged from 120 to $127 \mathrm{Mg} \mathrm{ha}^{-1}$ in areas under the CT and NT systems. When comparing areas under CT and NT in which the same amount of straw was added annually to the soil surface, there was a trend of increasing C stocks in NT. This fact can be attributed to the soil disturbance performed in the CT area in 1998 and 2003. Tillage operations result in soil aggregate disruption and exposure of the protected organic matter to microbial activity and consequently an increase in SOM losses and $\mathrm{CO}_{2}$ emissions to the atmosphere (Six et al., 1999; La Scala Jr et al., 2008). Moreover, tillage operations improve conditions for SOM decomposition because they temporarily reduce soil compaction, increase soil porosity, improve conditions of oxygenation and increase soil temperature.

Our results corroborated the conclusions of Cerri et al. (2011), in which tillage operations during sugarcane replanting increased loss of soil $\mathrm{C}$ and reduced the potential of soil $\mathrm{C}$ sequestration in areas of green cane cultivation. In general, it has been observed that the greater part of the $\mathrm{C}$ accumulated during the sugarcane cycle (around five years) is lost shortly after soil disturbance. In a short-term study carried out in the same region as the present study, La Scala Jr et al. (2006) confirmed this hypothesis and observed that the adoption of the NT system during sugarcane replanting reduced $\mathrm{CO}_{2}$ emissions when compared to CT. Over a period of 28 days, these authors observed that CT adoption increased the emis-

Table 2 - Soil C content and soil C stock in the different layers and management systems: baseline, conventional tillage (CT) and no-tillage (NT). Mean values for three replicates: mean values in line followed by the same letter do not differ (Tukey test: $p<0.05$ ).

\begin{tabular}{|c|c|c|c|c|c|}
\hline Soil layer (cm) & Baseline & $\mathrm{CT}$ & NT & $\mathrm{LSD}^{*}$ & $\mathrm{CV}^{* *}(\%)$ \\
\hline \multicolumn{6}{|c|}{ Soil $\mathrm{C}$ content $\left(\mathrm{g} \mathrm{kg}^{-1}\right)$} \\
\hline $0-5$ & $21.3 \pm 0.7 b$ & $20 \pm 1 b$ & $25.2 \pm 0.3 a$ & 2.1 & 4 \\
\hline $5-10$ & $19.9 \pm 0.1 \mathrm{a}$ & $19.8 \pm 0.7 a$ & $22 \pm 2 \mathrm{a}$ & 2.8 & 6 \\
\hline $10-20$ & $18.1 \pm 0.1 \mathrm{a}$ & $18.4 \pm 0.7 \mathrm{a}$ & $17.2 \pm 0.5 \mathrm{a}$ & 1.2 & 3 \\
\hline $20-60$ & $11.0 \pm 0.7 \mathrm{a}$ & $12 \pm 1 \mathrm{a}$ & $13 \pm 1 \mathrm{a}$ & 2.7 & 9 \\
\hline \multicolumn{6}{|c|}{ Soil C stock $\left(\mathrm{Mg} \mathrm{ha}^{-1}\right)$} \\
\hline $0-5$ & $14.4 \pm 0.8 b$ & $13.3 \pm 0.5 b$ & $16.9 \pm 0.3 a$ & 1.5 & 4 \\
\hline $5-10$ & $14.3 \pm 0.7 \mathrm{a}$ & $13.9 \pm 0.2 \mathrm{a}$ & $16 \pm 2 \mathrm{a}$ & 2.9 & 6 \\
\hline $10-20$ & $25.5 \pm 0.7 a$ & $26 \pm 2 \mathrm{a}$ & $24 \pm 2 a$ & 3.5 & 9 \\
\hline $20-60$ & $62 \pm 2 \mathrm{a}$ & $66 \pm 7 a$ & $70 \pm 5 a$ & 14.3 & 5 \\
\hline $0-60$ & $116 \pm 4 b$ & $120 \pm 5 a b$ & $127 \pm 4 a$ & 10.0 & 3 \\
\hline
\end{tabular}

*Least Significant Difference; * ${ }^{*}$ Variation of coefficient. 
sion by $8.4 \mathrm{Mg}$ of $\mathrm{CO}_{2}$ or $2.3 \mathrm{Mg}$ of $\mathrm{C}-\mathrm{CO}_{2}$ in relation to the NT area.

In a recent study based on long-term experiments in Australia, Thorburn et al. (2012) did not observe a direct relationship between the time of green cane adoption and increase in soil $\mathrm{C}$ stock. The main explanation for these results may be associated with tillage operations performed during sugarcane replanting and with the limited capacity of the soil to accumulate C. In the present study, the maintenance of straw on the soil surface resulted in $\mathrm{C}$ retention rates of 0.67 and $1.63 \mathrm{Mg}$ ha $^{-1}$ year $^{-1}$, respectively, for CT and NT systems, indicating that the association between maintaining straw on the soil surface and NT management /without soil disturbance) increases soil $\mathrm{C}$ stocks and reduces $\mathrm{CO}_{2}$ emissions to the atmosphere.

Despite the many benefits, the NT adoption is not yet widely used in sugarcane fields in Brazil. In general, the green cane soils are compacted in the replanting period, and in most of the cases CT and minimum tillage are used. The intense machinery traffic, resulting from transloaders and harvesters that harvest only one row at a time, results in a greater soil surface trampled causing soil compaction (Braunack and McGarry, 1998; Souza et al., 2012b) and hindering the NT adoption in its fullness. It is believed that the NT implementation in sugarcane fields should be linked to strategies to control and reduce traffic. Australian researchers indicated that control and reduction of traffic result in many benefits to sugarcane fields, especially reduction of the stumps trampling, reduction of soil compaction in areas destined to roots growth (Braunack and McGarry, 2006), increase in the rate of water infiltration and soil biological activity (Tullberg et al., 2007). All these benefits improve the conditions for sugarcane production. However, no studies are found in literature evaluating the NT adoption in sugarcane fields under controlled traffic conditions in Brazil and further studies are necessary.

\section{Humification index assessed by LIFS}

Lower humification indexes are verified at surface layers $(0-5 \mathrm{~cm})$ for all soil systems (Figure 1). At the top layer, lower $\mathrm{H}_{\mathrm{LIF}}$ can be associated with the occurrence of labile $\mathrm{C}$, since the constant input of plant residues overwhelms the capacity of microorganisms to metabolize them. In deeper layers, there is an increase of $\mathrm{H}_{\mathrm{LIF}}$ due to the presence of more recalcitrant $\mathrm{C}$. In these circumstances, $\mathrm{C}$ stability is higher since the input of residues is lower, and there is further decomposition of humic substances by microorganisms (Segnini et al., 2011). Baseline and CT presented similar $\mathrm{H}_{\mathrm{LIF}}(p>0.05)$ due to the effect of soil disturbance (plowing) present in both areas, keeping the surface soil layers more homogeneous. In contrast, NT soil presented a gradient of increasing the $\mathrm{H}_{\mathrm{LIF}}$ of SOM at deeper layers $(p<0.05)$ due to effect of non-soil disturbance. The entry of labile organic material, such as sugarcane straw, is also responsible for the accumulation of $\mathrm{C}$ in this system.

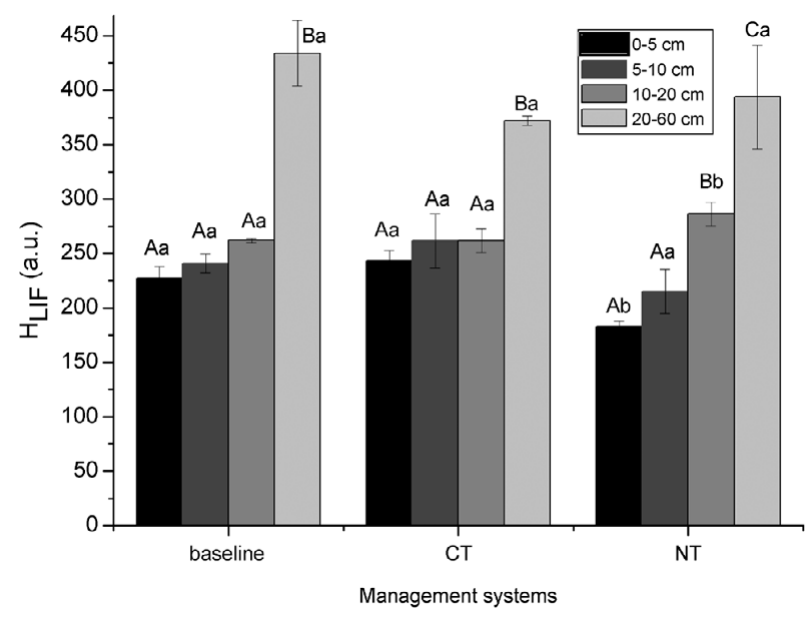

Figure 1 - Soil organic matter humification index $\left(\mathrm{H}_{\mathrm{LIF}}\right)$ obtained by Laser-Induced Fluorescence Spectroscopy in the different soil layers and management systems: baseline (sampled before establishment of soil management), conventional tillage (CT) and no-tillage (NT). Mean values for three replicates. Capital letters compare indexes of all depths for each management system and lower cases compare indexes of the same depth for all management systems. Mean values followed by the same letter do not differ (Tukey test: $p<0.05$ ).

The humification index at the first layer $(0-5 \mathrm{~cm})$ determined in NT soils was lower compared to CT and baseline $(p<0.05)$. These results are in agreement with previous studies (Bayer et al., 2002; González-Pérez et al., 2007; Favoretto et al., 2008). The presence of sugarcane straw also promotes changes in SOM humification. Sugarcane straw increases water retention in the soil (Peres et al., 2010) and consequently the straw will also change the dynamics of $\mathrm{C}$ (Robertson and Thorburn, 2007; Thorburn et al., 2012) and humification of SOM (Canellas et al., 2007; Panosso et al., 2011). The deposition of straw for a period of time promotes an increase of labile forms of organic matter because of the balance between the input of residue and its subsequent decomposition by microorganisms. The soil microbial activity $\left(\mathrm{CO}_{2}\right.$ production) and soil microbial biomass increase under green cane systems is a consequence of improved C availability (Robertson and Thorburn, 2007).

The management is important to soil C content improvement and its quality, since the crop residues added to the surface under NT would be only partially decomposed, resulting in less humified organic matter, while the crop residues that were incorporated into the plow layer in CT soil result in a large stimulation of soil microorganisms (Bayer et al., 2002). Favoretto et al. (2008) applied LIFS to determine the $\mathrm{H}_{\mathrm{LIF}}$ of soils and of their organic-matter fractions, observing that, on the surface of the soil, NT provided the smallest $\mathrm{H}_{\mathrm{LIF}}$ in comparison with $\mathrm{CT}$ and reduced tillage. The accelerated decompo- 
sition of more labile portions of SOM was observed in $\mathrm{CT}$ as a function of intense soil disturbance, resulting in a relative increase of recalcitrant structures. On the other hand, the preservation of labile structures through physical protection mechanisms or soil aggregation occurs under NT.

In a study related to the impact of soil management on C loss and C stability, Barreto et al. (2009) showed that NT is an efficient soil management system for enhancing SOM accumulation and stabilizing labile $\mathrm{C}$ in soil structures after a continuous CT system. Barreto et al. (2009) also assessed the aggregation properties of these tillage systems, concluding that a large part of the organic matter in NT is stabilized by soil aggregation in a labile form. As a result, NT systems have to be maintained or improved, since any degradation in the soil aggregation state would result in $\mathrm{C}$ loss as $\mathrm{CO}_{2}$ from the system. Using Electron Spin Resonance spectroscopy and determining recalcitrant C, Bayer et al. (2000, 2002) show that the concentration of semiquinone free radicals is generally higher in humic acids and physical fractions of soils under CT (under low input cropping systems) than in soils under NT. These indications are related to higher tillage intensity and lower residue addition, in which only the most recalcitrant structures of SOM tend to remain.

The presence of sugarcane straw seems to be an efficient pathway for the recuperation of soil in terms of $\mathrm{C}$ stocks, in spite of the fact that incorporation of straw in CT did not improve soil $\mathrm{C}$ accumulation after seven years of experiment. The changes in this set of factors, influenced by the management effect and the maintenance of sugarcane straw, were reflected in changes in the chemical nature of the humic acids (Canellas et al., 2007) as an indicator of SOM quality.

\section{Conclusions}

The maintenance of straw on the soil surface and the adoption of NT during sugarcane planting are strategies that increase soil $\mathrm{C}$ accumulation in the Brazilian sugarcane sector in areas of green cane cultivation. The adoption of NT resulted in annual $\mathrm{C}$ retention rates of $1.63 \mathrm{Mg} \mathrm{ha}^{-1} \mathrm{year}^{-1}$, while the association between straw on the soil surface and CT during sugarcane replanting accumulated only $0.67 \mathrm{Mg} \mathrm{ha}^{-1}$ year $^{-1}$. In terms of $\mathrm{C}$ accumulation, this study indicates that the adoption of conservation tillage during sugarcane replanting is as important as the maintenance of straw on the soil surface in the crop cycle.

Laser-Induced Fluorescence Spectroscopy results indicated that the effect of maintaining sugarcane straw on the topsoil under the NT system was lower $\mathrm{H}_{\text {LIF }}$ when compared to $\mathrm{CT}$ and the baseline. The constant input of $\mathrm{C}$ and the preservation of labile structures on the soil make the NT system the most appropriate soil management for sugarcane replanting areas, given its low environmental impact on soils.

\section{Acknowledgements}

We are grateful for financial support from "The State of São Paulo Research Foundation" (FAPESP) (project: 03/06084-0 and fellowship to A. Segnini project: 03/06096-8), as well as to the EMBRAPA (project: 01.02.1.03.02.05) and National Council for Scientific and Technological Development (CNPq) for the research fellowship.

\section{References}

Barreto, R.C.; Madari, B.E.; Maddock, J.E.L.; Machado, P.L.O.A.; Torres, E.; Franchini, J.; Costa, A.R. 2009. The impact of soil management on aggregation, carbon stabilization and carbon loss as $\mathrm{CO} 2$ in the surface layer of a Rhodic Ferralsol in Southern Brazil. Agriculture, Ecosystems and Environment 132: 243-251.

Bayer, C.; Martin-Neto, L.; Mielniczuk, J.; Ceretta, C.A. 2000. Effect of no-till cropping systems on soil organic matter in a sandy clay loam Acrisol from Southern Brazil monitored by electron spin resonance and nuclear magnetic resonance. Soil and Tillage Research 53: 95-104.

Bayer, C.; Mielniczuk, J.; Martin-Neto, L.; Ernani, P.R. 2002. Stocks and humification degree of organic matter fractions as affected by no-tillage on a subtropical soil. Plant and Soil 238: 133-140.

Bayer, C.; Martin-Neto, L.; Mielniczuk, J.; Pavinato, A.; Dieckow, J. 2006. Carbon sequestration in two Brazilian cerrado soils under no-till. Soil and Tillage Research 86: 237-245.

Blair, G.J.; Chapman, L.; Whitbread, A.M.; Ball-Coelho, B.; Larsen, P.; Tiessen, H. 1998. Soil carbon changes resulting from sugarcane trash management at two locations in Queensland, Australia, and in North-East Brazil. Australian Journal of Soil Research 36: 873-882.

Braunack, M.V.; McGarry, D. 1998. Is all that tillage necessary? Australian Sugarcane 1: 12-14.

Braunack, M.V.; McGarry, D. 2006. Traffic control and tillage strategies for harvesting and planting of sugarcane (Saccharum officinarum) in Australia. Soil and Tillage Research 89: 86-102.

Canellas, L.P.; Baldotto, M.A.; Busato, J.G.; Marciano, C.R.; Menezes, S.C.; Da Silva, N.M.; Rumjanek, V.M.; Velloso, A.C.X.; Simões, M.L.; Martin-Neto, L. 2007. Stocks and quality of organic matter in an inceptisol under long-term sugarcane cultivation. Revista Brasileira de Ciência do Solo 31: 331-340 (in Portuguese, with abstract in English).

Cerri, C.C.; Galdos, M.V.; Maia, S.M.F.; Bernoux, M.; Feigl, B.J.; Powlson, D.; Cerri, C.E.P. 2011. Effect of sugarcane harvesting systems on soil carbon stocks in Brazil: an examination of existing data. European Journal of Soil Science 62: 23-28.

Companhia Nacional de Abastecimento [CONAB]. 2011. Monitoring of the Brazilian crop: sugarcane; agricultural year 2010/2011, first survey in December 2011. Available at: http:// www.conab.gov.br/detalhe.php?c $=27292 \& t=2 \#$ this/ [Accessed Aug. 10, 2012].

Ellert, B.H.; Bettany, J.R. 1995. Calculation of organic matter and nutrients stored in soils under contrasting management regimes. Canadian Journal of Soil Science 75: 529-538. 
Favoretto, C.M.; Gonçalves, D.; Milori, D.M.B.P.; Rosa, J.A.; Leite, W.C.; Brinatti, A.M.; Saab, S.C. 2008. Determination of humification degree of organic matter of an Oxisol and of its organic mineral fractions. Química Nova 31: 1994-1996 (in Portuguese, with abstract in English).

Federação Brasileira de Plantio Direto na Palha [FEBRAPDP]. 2012. Available at: http://www.febrapdp.org.br/ [Accessed Jul. 1, 2012].

Galdos, M.V.; Cerri, C.C.; Cerri, C.E.P. 2009. Soil carbon stocks under burned and unburned sugarcane in Brazil. Geoderma 153: 347-352.

González-Pérez, M.; Milori, D.M.B.P.; Colnago, L.A., Martin-Neto, L.; Melo, W.J. 2007. A laser-induced fluorescence spectroscopic study of organic matter in a Brazilian Oxisol under different tillage systems. Geoderma 138: 20-24.

La Scala Jr, N.; Bolonhezi, D.; Pereira, G.T. 2006. Short-term soil $\mathrm{CO}_{2}$ emission after conventional and reduced tillage of a no-till sugarcane area in southern Brazil. Soil and Tillage Research 91: 244-248.

La Scala Jr, N.; Lopes, A.; Spokas, K.; Bolonhezi, D.; Archer, D.; Reicosky, D.C. 2008. Short-term temporal changes of soil carbon losses after tillage described by a first-order decay model. Soil and Tillage Research 99: 108-118.

Magalhães, P.S.G.; Nogueira, L.A.H.; Cantarella, H.; Rossetto, R.; Franco, H.C.J.; Braunbeck, O.A. 2012. Agro-industrial technological paths. p. 27-69. In: Sustainability of sugarcane bioenergy. Center of Strategic Studies and Management, Brasília, DF, Brazil.

Milori, D.M.P.B.; Galeti, H.V.A.; Martin-Neto, L.; Diekow, J.; González-Peréz, M.; Bayer, C.; Salton, J. 2006. Organic matter study of whole soil samples using laser-induced fluorescence spectroscopy. Soil Science Society of America Journal 70: 57-63.

Milori, D.M.P.B.; Segnini, A.; da Silva, W.T.L.; Posadas, A.; Mares, V.; Quiroz, R.; Martin-Neto, L. 2011. Emerging techniques for soil carbon measurements. p. 252-262. In: Wollenberg, E.; Nihart, A.; Tapio-Biström, M.L.; Grieg-Gran, M., eds. Climate change, mitigation and agriculture. CGIAR Research Program on Climate Change, London. UK.

Monquero, P.A.; Amaral, R.L.; Binha, D.P.; Silva, P.V.; Silva, A.C.; Martins, F.R.A. 2008. Weed infestation maps under different sugarcane harvest systems. Planta Daninha 26: 47-55 (in Portuguese, with abstract in English).

Nelson, D.W.; Sommers, L.E. 1982. Total carbon, organic, and organic matter. p. 539-579. In: Page, A.L.; Miller, R.H.; Keeney, D.R. eds. Methods of soil analysis. Part 2. American Society of Agronomy, Madison, WI, USA.

Oliveira, M.W.; Trivelin, P.C.O.; Penatti, C.P.; Piccollo, M.C. 1999. Field decomposition and release of sugar cane trash nutrients. Pesquisa Agropecuária Brasileira 34: 2359-2362 (in Portuguese, with abstract in English).

Panosso, A.R.; Marques Jr, J.; Milori, D.M.B.P.; Ferraudo, A.S.; Barbieri, D.M.; Pereira, G.T.; La Scala Jr, N. 2011. Soil CO emission and its relation to soil properties in sugarcane areas under Slash-and-burn and Green harvest. Soil and Tillage Research 111: 190-196.

Peres, J.G.; Souza, C.F.; Lavorenti, N.A. 2010. Evaluation of the effects of sugarcane straw coverage in moisture and water loss of soil. Engenharia Agrícola 30: 875-886 (in Portuguese, with abstract in English).
Robertson, F.A.; Thorburn, P.J. 2007. Management of sugarcane harvest residues: consequences for soil carbon and nitrogen. Australian Journal of Soil Research 45: 13-23.

Sá, J.C.; Cerri, C.C.; Dick, W.A.; Lal, R.; Venzke Filho, S.P.; Piccolo, M.C.; Feigl, B.J. 2001. Organic matter dynamics and carbon sequestration rates for a tillage chronosequence in a Brazilian oxisol. Soil Science Society of America Journal 65: 1486-1499.

Segnini, A.; Posadas, A.; Quiroz, R.; Milori, D.M.B.P.; Saab, S.C.; Vaz, C.M.P.; Martin-Neto, L. 2010. Spectroscopic assessment of soil organic matter in wetlands from the high Andes. Soil Science Society of America Journal 74: 2246-2253.

Segnini, A.; Posadas, A.; Quiroz, R.; Milori, D.M.B.P.; Vaz, C.M.P.; Martin-Neto, L. 2011. Comparative assessment of soil carbon stocks and stability in different agroecologies in southern Peru. Journal of Soil and Water Conservation 66: 213-220.

Sisti, C.P.J.; Santos, H.P.; Kohhann, R.; Alves, B.J.R.; Urquiaga, S.; Boddey, R.M. 2004. Change in carbon and nitrogen stocks in soil under 13 years of conventional or zero tillage in southern Brazil. Soil and Tillage Research 76: 39-58.

Six, J.; Elliott, E.T.; Paustian, K. 1999. Aggregate and soil organic matter dynamics under conventional and no-tillage systems. Soil Science Society of American Journal 63: 1350-1358.

Souza, R.A.; Telles, T.S.; Machado, W.; Hungria, M.; Tavares Filho, J.; Guimarães, M.F. 2012a. Effects of sugarcane harvesting with burning on the chemical and microbiological properties of the soil. Agriculture, Ecosystems and Environment 155: 1-6.

Souza, G.S.; Souza, Z.M.; Silva, R.B.; Araújo, F.S.; Barbosa, R.S. 2012b. Soil compressibility and root system of sugarcane with and without controlled-traffic farming. Pesquisa Agropecuária Brasileira 47: 603-612 (in Portuguese, with abstract in English).

Sparovek, G.; Schnug, E. 2001. Soil tillage and precision agriculture: a theoretical case study for soil erosion control in Brazilian sugar cane production. Soil Tillage Research 61: 4754.

Thorburn, P.J.; Meier, E.A.; Collins, K.; Robertson, F.A. 2012. Changes in soil carbon sequestration, fractionation and soil fertility in response to sugarcane residue retention are sitespecific. Soil and Tillage Research 120: 99-111.

Trivelin, P.C.O.; Victoria, R.L.; Rodrigues, J.C.S. 1995. Utilization by late harvest sugar cane ratoon of nitrogen from ${ }^{15} \mathrm{~N}$ aqua ammonia and ${ }^{15} \mathrm{~N}$-urea applied to the soil as vinasse N-complement. Pesquisa Agropecuária Brasileira 30: 13751385 (in Portuguese, with abstract in English).

Trivelin, P.C.O.; Oliveira, M.W.; Vitti, A.C.; Gava, G.J.C.; Bendassolli, J.A. 2002. Nitrogen utilization and sugarcane (plant cane) yield on a sandy soil with incorporated crop residues. Revista Brasileira de Ciência do Solo 26: 636-646 (in Portuguese, with abstract in English).

Tullberg, J.N.; Yule, D.F.; McGarry, D. 2007. Controlled traffic farming - from research to adoption in Australia. Soil and Tillage Research 97: 272-281.

van Raij, B.; Andrade, J.C.; Cantarella, H.; Quaggio, J.A. 2001. Análise Química para Avaliação da Fertilidade de Solos Tropicais = Chemical Analysis to Assess the Fertility of Tropical Soils. Instituto Agronômico, Campinas, SP, Brazil (in Portuguese). 